Historic, Archive Document

Do not assume content reflects current scientific knowledge, policies, or practices. 



\section{SPECIAL SPRING}

PRICE LIST 11

of

HARDY PERENNIAL PLANTS

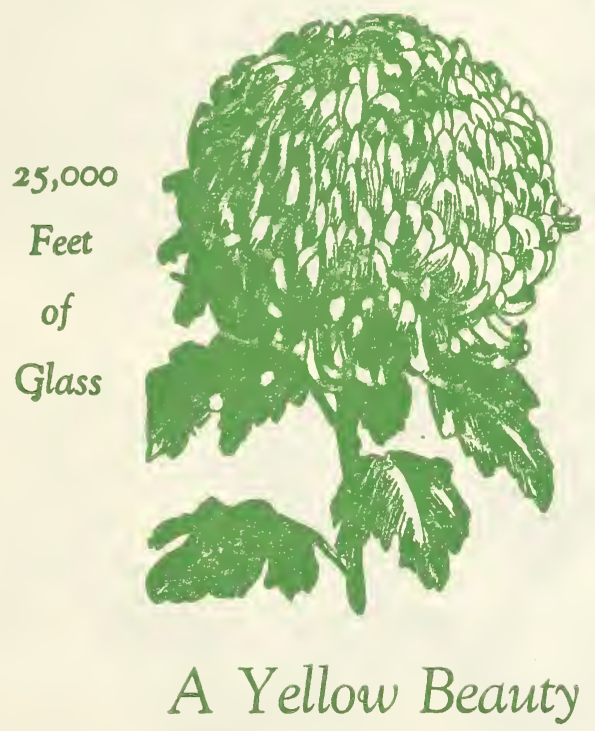

NOTE: PLEASE BEAR IN MIND THAT EACH AND EVERY ITEM LISTED HEREIN IS GROWN ON MY OWN PREMISES

\section{ADOLPH FISCHER WHOLESALE FLORIST EASTON, PA.}




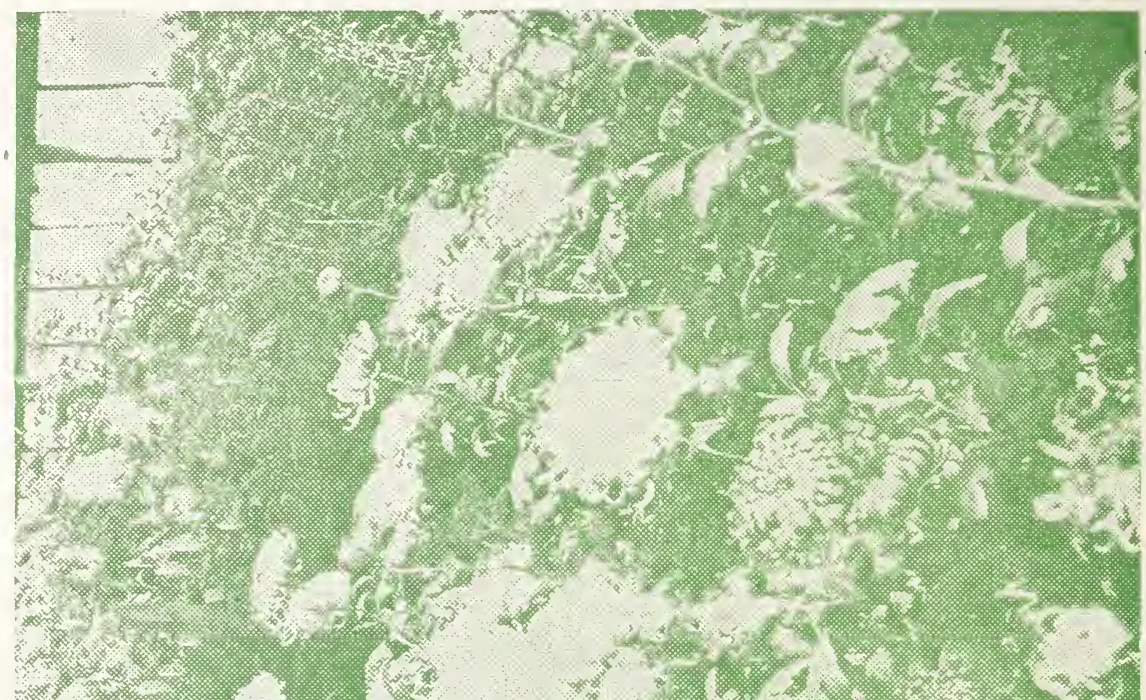
The

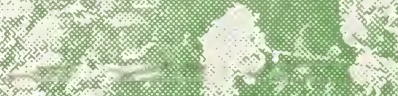

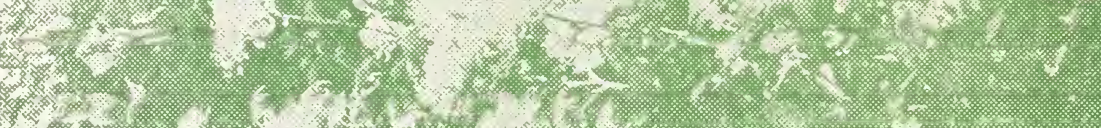

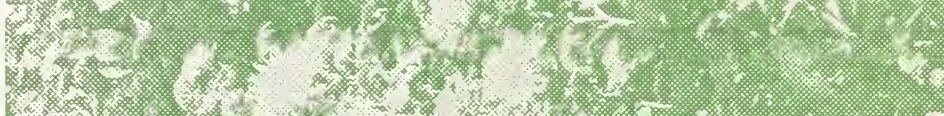

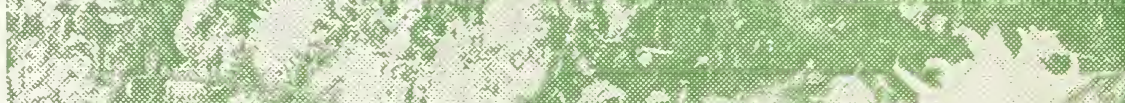

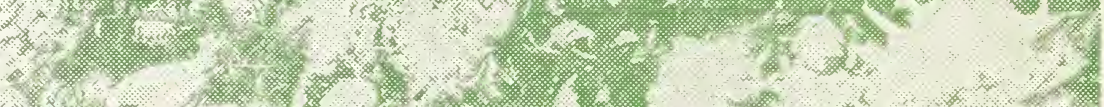

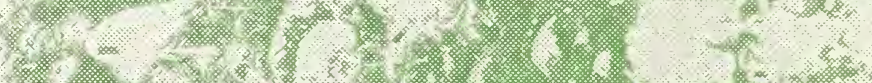

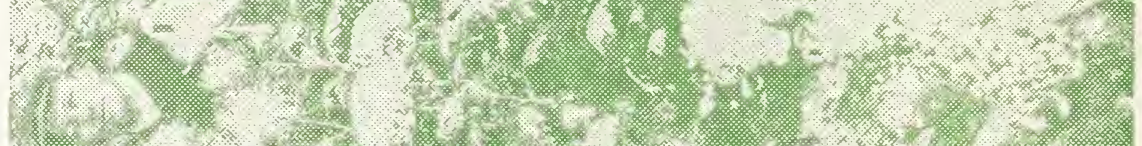

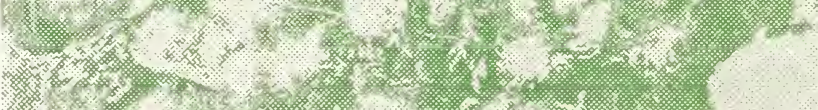

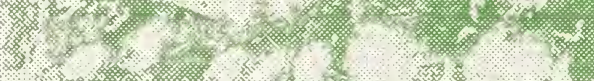

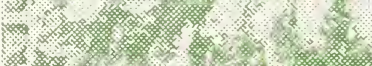

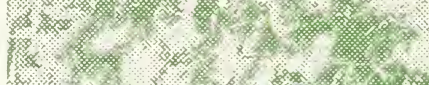

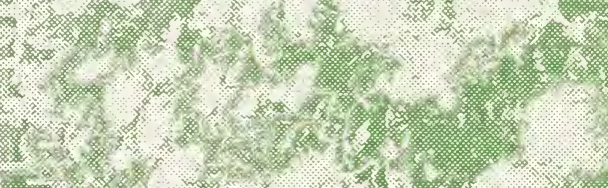

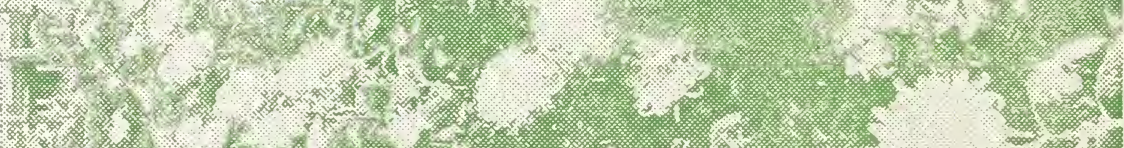

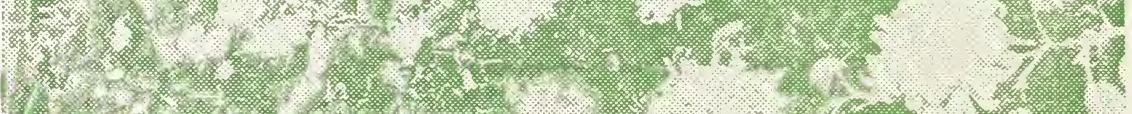
1.

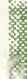

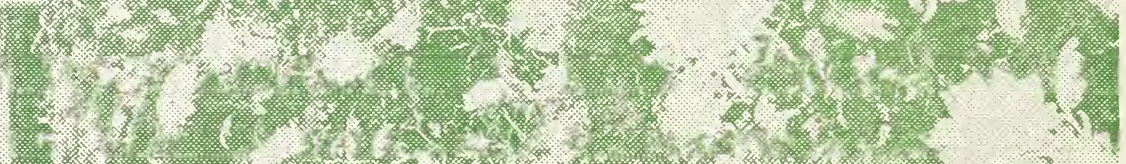

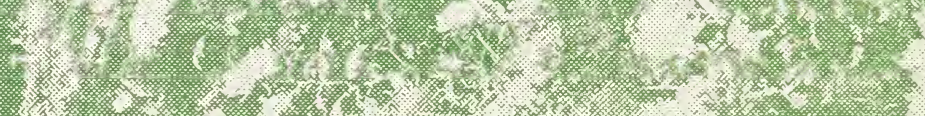
綝

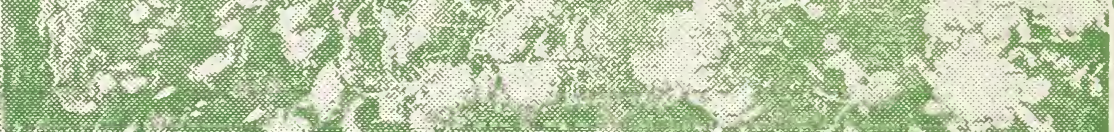

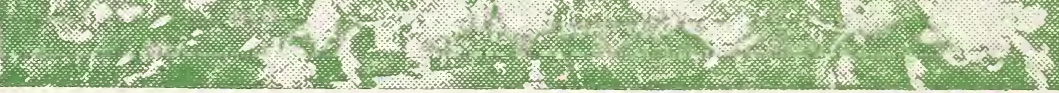




\section{Chrysanthemums}

HARDY EXIHBITION CHRYSANTHEMUM-Bronze, Pink, Lav. ender, White, Red and Yellow, flowers measure 4 to 6 inches in dia. meter. Bloom August, September, October each year. These are beauties.

We reserve the right to substitute for colors not in stock when your order is received, to avoid delay in making shipment.

Our collection contains the best and most beautiful of the newer varieties, as well as the choicest of the standard sorts. We offer them at prices within the reach of all, as we would like to see them growing in every gar. den and in every home.

VERY LARGE FLOWERING VARIETIES.

OCONTO-Pure white. Immense large.

AUNT MARY - Old Rose color.

UNAKA-Pink. Enormous size.

CANARY BIRD-Rich golden-yellow; extra.

EXCELSIOR-Rich, fine yellow.

TINTS OF GOLD - Extra large.

GLORY OF SEVEN OAKS (Carrie)-Deep golden yellow; a beauty.

SUN GLOW-A yellow beauty. Immense size.

INDIAN-A fine shade of Indian-red.

JACK FROST - Snow-white; very free flowering.

OLD LAVENDER-A beautiful shade of lavender.

CRANFORDS WHITE-Very large.

GOACHERS CRIMSON-A beauty.

MME. F. NONIN-Delicate pink.

MADUSE-Very fine bronze.

6 Plants for

$\$ 1.10$

GRAND PRIZE COLLECTION-The World's Newest and Largest Exhibition Varieties. The Six Varieties Given Below Are the Best in Their Several Classes and Colors. Of the many Chrysanthemums which we grow the following varieties are the finest, largest and most easily grown. These famous varieties can be seen in full bloom in our Greenhouses in October and early November and we wish all could come and see them.

GOLDEN CHADWICK-When high-class blooms are the object, this variety reigns supreme. Its rich yellow color, combined with the good characteristics of the Chadwicks, places it as one of the best late yellows.

W. H. CHADWICK-For the markets that want select stock, this variety stands alone. Slightly pinkish when grown cool, it is even more charming than when pure white.

CHADWICK SUPREME-Color variegated. (A Beauty).

CHIEFTAIN-Deep, clear pink; incurved in type.

EDWIN SEIDEWITZ $-A$ beautiful late incurved; bright pink.

PINK TREASURE-A new variety of the brightest possible pink color. Large flowers and one of the best growers.

Each 20c, or 6 for

Grow these six Varieties in 6 to 8 inch flower pots, plungo same in ground, keep in your garden during the summer; before danger of frost, transfer to a sunny window. They will then bloom indoors for a long time. 


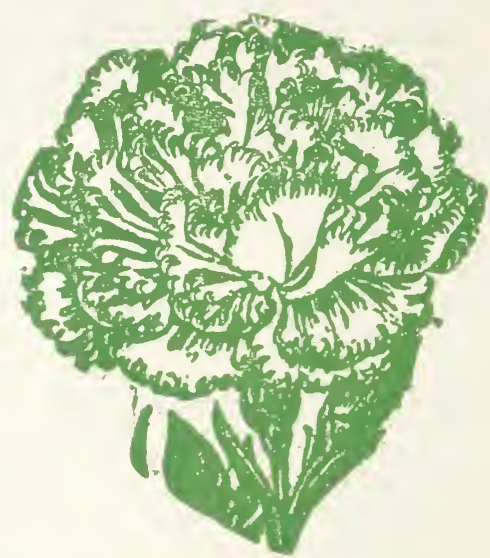

\section{Hardy Carnation, Very Fragrant} (GRENADINE)

These Grenadine carnations belong to the eldest and solidest early blooming varieties of the numerous kinds of carnations. They are known as thankful 1 owers, fit for groups and beddings by their compact and symmetrical growth; of highest effect in the season's producing flowers by flowers.

Plant carnations 1 foot apart each way and use good garden soil, mix with old manure, water early in the morning during hot summer days. If large flowers are wanted, grow only one bud on each stem. These fine, hardy Grenadine Carnations produce $80 \%$ of the finest fragrant double flowers.

"RED FANTASTIC COLOUR"
Fiery Scarlet
Fiery Red
"BRING OF THE BLACK"
Dark Chestnut Colored.
Shining Snow-White.
"GOLDEN YELLOW"

Stay outdoors during the winter.

6 Plants for

\section{HOLLYHOCK}

12 Plante for

Chaters double, Crimson, Yellow, Salmon, White, Rose, Maroon, Newport

Pink and Mized. Very hardy and extra fine.

EXHIBITION CANNAS-.-Dwarf,'very:large flowering. Yellow, Red, Pink. A beauty.

6 Bulbs for

WE SHIP THESE VARIETIES DURING APRIL, MAY, JUNE, JULY 


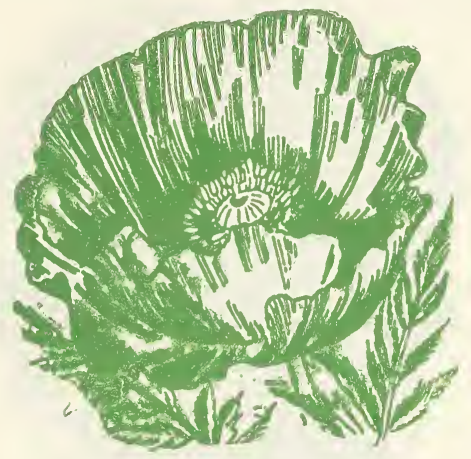

ORIBNTAL POPPY-Scarlet, Orange, Pink, flowers, measure 6 inches in diameter. (Last for ever.)

12 Plants for

CHOICB HARDY LARGB FLOWBRING PERENNIAL PHLOX

6 Plants for

Diveraified and brilliant colors, profuse and continuous bloom. Place Hardy $\mathrm{Phlox}$ in the front rank of desirable flowering plants. Being perfectly hardy, once planted they improve and multiply in vigor and beauty each successive year. Should be kept well watered.

SWEBT WILLIAM-All color, hardy, free bloomer.

12 Plante for $\$ 1.10$

BNGLISH DAISY OR BELLIS.

White and Pink, very hardy.

12 Plants for

\section{DIGITALIS FOX GLOVE.}

White Spotted, Rose, Purple and mired. Blooms all summer.

6 Plants for

\section{Delphinium, Belladonna \\ DELPHINIUM \\ (Perennial Larkapur)}

BBLLADONNA - Light turquoise blue.

BBLLAMOSUM- $A$ dark blue type of the Belladonna.

Very decorative, and last for years.

6 Plant for

WE SHIP THESE VARIETIES DURING APRIL, MAY, JUNE, JULY 
Don't wait for seed to come up. OUR PLANTS bloom the WHOLE SEASON.

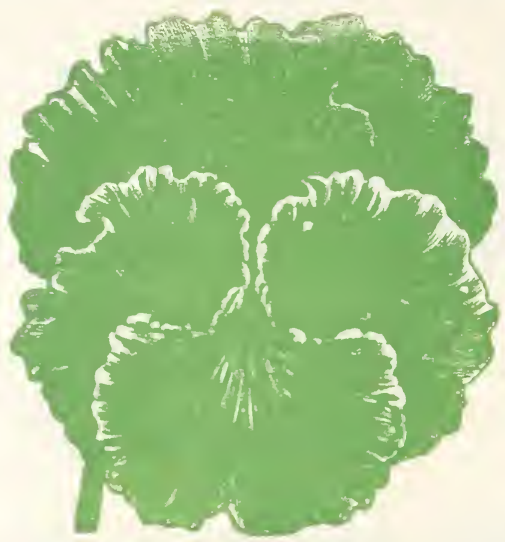

PANSY_Giant flowering in bud, all colors.

25 Plants for

FRAGRANT HARDY VIOLETS.

(Large Blue Single)

6 Plants for $\$ 1.10$

Shasta Daisy "Alaska." Pure white.

Flowers measure 4 inches in diameter.

6 Plants for $\$ 1.10$

\section{COLUMBINE ASSORTED}

Very attractive.

6 Plants for $\$ 1.10$

HARDY HYDRANGEAS P. G. (Tree-shape)

3 Plants for (Last Forever)

\section{GIANT ASTERS}

Large flowering, early and late varieties. White, Rose, Lavender, Purple and Shell pink. Blood red, silvery. Florists' selected beauties.

40 Plants (transplanted) $\$ 1.10$

\section{GLADIOLUS BULBS}

Exhibition Varieties assorted-finest colors.

25 Bulbs for $\$ 1.10$

\section{GAIILARDIA}

Hardy, beautiful color. Velvet, Yellow, Orange.

12 Plants for $\$ 1.10$

BLEEDING HEARTS (LAST FOREVER).

Very sweet.

2 Plants for $\$ 1.10$

WE SHIP THESE VARIETIES DURING APRIL, MAY, JUNE, JULY 


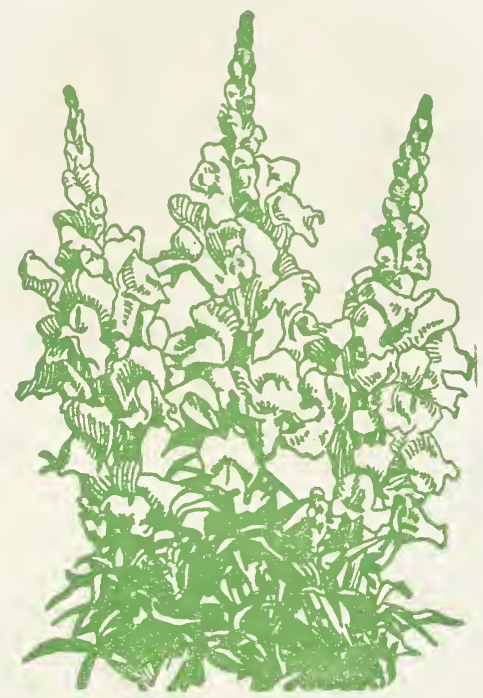

NOVELTY SNAPDRAGONS

Salmon, Yellow, White, Crimson, Rose Pink, Red, Variegated. Dark Pink and other beautiful colors.

40 Plants (transplanted) $\$ 1.10$

HARDY BUTTERFLY BUSH or SUIMMER LILAC

A pretty shrub of spreading habit, growing $4 \frac{1}{2}$ to 6 feet high and flowering freely the first season. The long tapering flower'spikes, often 12 to 15 inches long, are covered densely with lilac-like violet-mauve colored blooms from June till frost. Delightfully fragrant. During the sum. mer months this plant is a mecca for butterflies, and for this reason it is named the "Butterfly Bush." (Last forever.)

3 Plants for $\$ 1.10$

\section{GYPSOPHILA (Baby's Breath)}

Free flowering plants of easy culture, excellent for cutting to mix with other flowers.

6 Plants for $\$ 1.10$

NO GUARANTEE-While I exercise the utmost care in executing all orders, to keep my stock true to name, I give no warranty, expressed or implied, and cannot guarantee or be in any way responsible for the crop, either as to variety or product. If not accepted on these terms, they must be returned at once. If paid in advance your money will be returned at once.

All PLANTS and PERISHABLE GOODS shipped by freight, ex. press or Parcel Post at buyer's risk. 


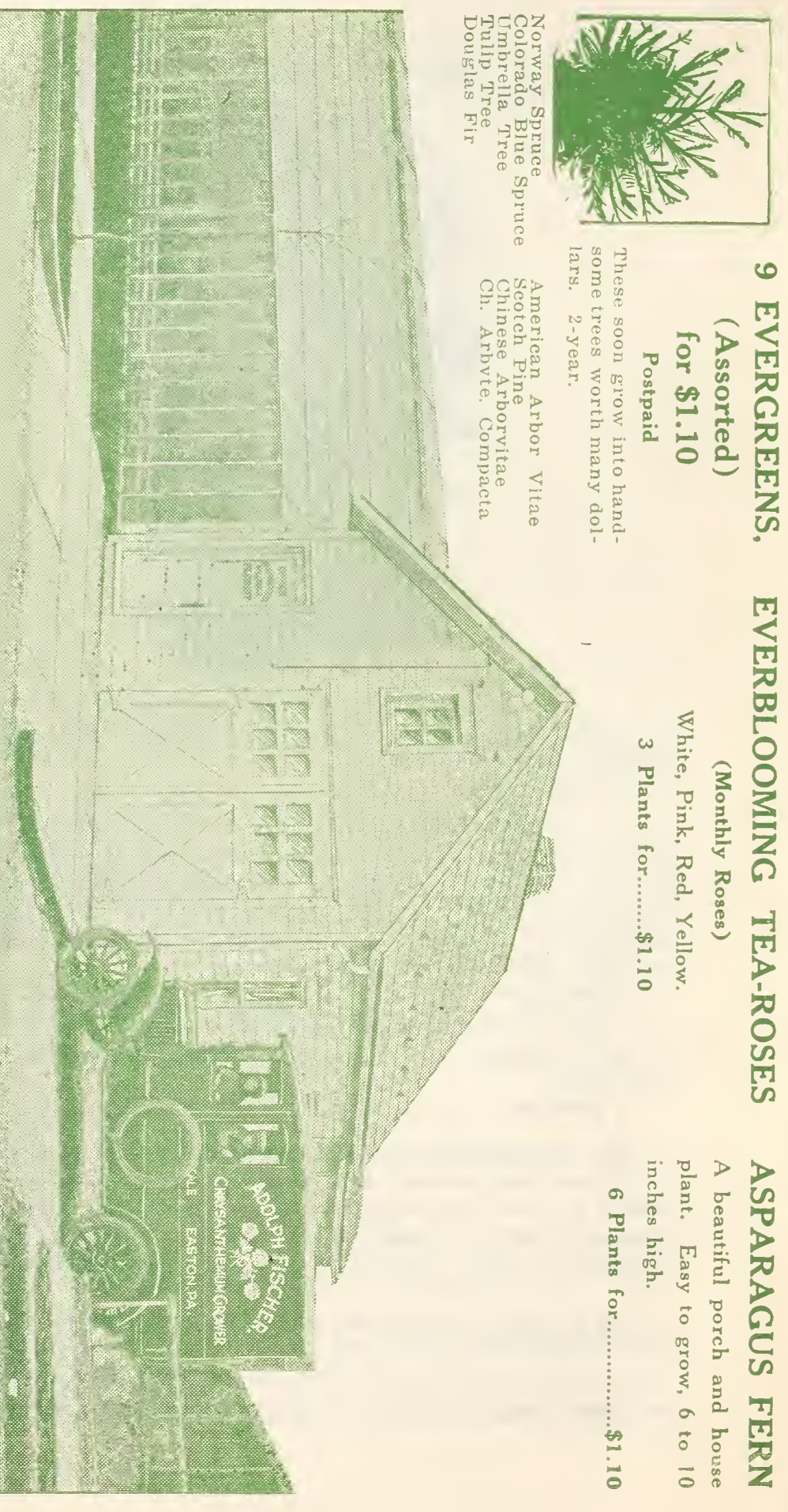

